Karina Kinga Kozłowska*

Kraków

\title{
Wariacje na temat mediacji w związku z koncepcją liberal education
}

Celem niniejszego artykułu jest wgląd w instytucję mediacji pod kątem obecności w niej elementów, wynikających z założeń liberal education. Autor artykułu wyprowadza je z przedmiotu rozważań, którego centrum stanowią oświeceniowe cechy człowieka wolnego oraz odpowiedzialnego za kreowanie własnej rzeczywistości. Uzasadnienie powyższej tezy wymaga przedtem przedstawienia sposobu rozumienia liberal education oraz wskazanie na najważniejsze cechy mediacji, jako jednego z alternatywnych sposobów rozwiązywania sporów. Z uwagi na skromny dorobek myśli naukowej na gruncie polskiej refleksji pedagogicznej dotyczącej zarówno mediacji, jak i liberal education, oraz niepodejmowanej dotąd refleksji uwzględniającej potencjał zaistnienia mediacji w perspektywie koncepcji edukacyjnej, poniższe rozważania stają się przyczynkiem do dalszej dyskusji.

Właściwa analiza przyjętej problematyki wymaga dookreślenia jej zakresu, wyznaczając tym samym obszar zainteresowań autora. Zamiarem bowiem nie jest opis liberal education z perspektywy efektów formalnego kształcenia czy systemu nauczania, a koncentracja na jej właściwościach, mających na celu intelektualny, społeczny oraz moralny rozwój jednostki. Dlatego koncepcja liberal education zostaje ujęta jako system założeń, mający na celu autonomiczny i skoncentrowany na humanistycznych warto-

* Mgr Karina Kinga Kozłowska jest doktorantką w Instytucie Pedagogiki Uniwersytetu Jagiellońskiego w Krakowie. 
ściach rozwój jednostki. Z kolei literatura przedmiotu wskazuje na współwystępowanie licznych zakresów znaczeniowych mediacji, wynikających między innymi z przyjmowania przez ich autorów odmiennych celów procedury mediacji ${ }^{1}$, warunkujących z kolei kształt poszczególnych paradygmatów mediacyjnych. $\mathrm{Z}$ tej przyczyny wykładnią prowadzonych rozważań będzie optymalizacyjny model paradygmatu mediacyjnego, który uwzględnia przyjęte $\mathrm{w}$ artykule najważniejsze cele mediacji ${ }^{2}$, warunkujące sukces oraz efektywność dyskursu mediacyjnego ${ }^{3}$.

\section{Wstępne założenia liberal education}

Rozważania, mające na celu przybliżenie koncepcji liberal education, należy poprzedzić refleksją, która odnosi się do trudności w wyznaczaniu jej jednorodnego terminologicznego znaczenia ${ }^{4}$. W swej pierwotnej postaci, jako historyczna tradycja akademicka, odwoływała się do starożytnej i średniowiecznej filozofii sztuk wyzwolonych (artes liberales), koncentrujących się na holistycznym rozwoju człowieka, to jest trosce o jego charakter, aktywną postawę obywatelską czy osiągnięcia w nauce. Edukacja liberalna, w przeciwieństwie do kształcenia zawodowego, koncentruje się na rozwoju wewnętrznym jednostki, nie warunkując jej kształcenia koniecznością podjęcia pracy bezpośrednio związanej z wykształceniem ${ }^{5}$. Dlatego termin $l i$ beralny opowiada się za wolnością myśli, sumienia oraz ideą, że instytucje

1 Terminy procedury oraz dyskursu mediacyjnego traktowane są synonimiczne, ponieważ w najszerszym znaczeniu odwołują się do mediacji jako sekwencyjnego procesu i postępowania dochodzenia do porozumienia.

${ }^{2}$ W optymalizacyjnym modelu dyskursu mediacyjnego wyróżnia się cele nadrzędne oraz podrzędne, które uwzględniają między innymi rozwój jednostki w wymiarze personalnym, interpersonalnym oraz społecznym, Zob. A. Zienkiewicz, Studium mediacji. Od teorii ku praktyce, Warszawa 2007, s. 115-122.

3 Optymalizacyjny model dyskursu mediacyjnego jest autorską koncepcją Adama Zienkiewicza, która stanowi połączenie dwóch najpopularniejszych, wykorzystywanych w mediacji paradygmatów: problem-solving mediation i transformative mediation. Zob. A. Zienkiewicz, Studium, s. 44.

${ }^{4}$ K. Wrońska, Liberal Education in Selected Polish Pedagogical Concepts - in Comparison to English-language Concepts - with Particular Reference to the Enlightenment (Period 2), „Kultura i Wychowanie” 6 (2013), s. 6.

${ }^{5}$ C. Winch, J. Gingell (red.), Philosophy of Education. The Key Concepts, London and New York 2008, s. 121n. - hasło: liberal education. 
społeczne koncentrują się na interesach oraz potrzebach jednostki, nie uzależniając ich od własnego charakteru działalności.

Recepcja liberal education oraz określenie jej w kontekście postaw znajduje odzwierciedlenie w stawianych przez greckich filozofów postulatach, wskazując na trzy płaszczyzny rozumienia edukacji liberalnej ${ }^{6}$. Pierwsza znajduje się w opozycji do przemijających wartości oraz tego, co jest niepewne oraz nieprawdziwe. $Z$ kolei druga stanowi spełnienie (ang. fulfilment) umysłu, którego nie sposób powiązać z utylitarystycznymi rozważaniami bądź zawodowym doświadczeniem, czyniąc ją pod tym względem najbardziej wartościowym kształtem edukacji. Trzeci aspekt akcentuje rolę liberal education w życiu człowieka, stanowiąc istotę odpowiedzi na pytanie, jak powinno się dobrze żyć? Co więcej, odwołując się do greckiej tradycji filozoficznej, termin liberalny należy utożsamiać z wolnym umysłem człowieka, który stanowiąc o jego naturze, pozwala mu stronić od popełniania błędów.

Źródła pojęcia liberal education w greckich doktrynach filozoficznych odnosiły się do doniosłej roli wiedzy dla umysłu oraz jej związku z rzeczywistością. Osiąganie wiedzy (ang. knowledge) stanowiło czynnik determinujący dobre życie człowieka, co oznaczało tyle, że realizacja wiedzy zaspokaja i spełnia umysł jednostki, który osiąga tym samym właściwy dla siebie cel, to jest rozwój w obszarze umiejętności, cnót lub innych cech, które stanowią o jego dobrym życiu. Poszukiwanie wiedzy staje się zarówno dobrem dla umysłu, jak i cechą go wyróżniającą ${ }^{7}$.

W perspektywie próby znalezienia wspólnej wykładni dla liberal education i mediacji ważny staje się wiek XX oraz refleksje w obszarze filozofii edukacji lat 60. Wskazano bowiem nie tylko na własności umysłu jednostki, które powinny być rozwijane na każdym etapie kształcenia, ale zwrócono także uwagę na powszechny i uniwersalny wymiar liberal education, pozbawiając ją tym samym elitarnego charakteru. Przykład zmian stanowią programy nauczania, za pośrednictwem których w miejsce powierzchownego łączenia poszczególnych faktów naukowych, przekazywana wiedza zaczęła stanowić spójną płaszczyznę poznania wielu dziedzin nauki. W związku z tym wiedza osoby wyedukowanej (educated man) implikowała dojrzałą oraz szeroką perspektywę poznawczą, odzwierciedlającą się w otwarciu oraz satysfakcji z podejmowania skoncentrowanych wokół własnego rozwoju aktywności. Edukacja ujmowana jako progres (reforma) zakłada bowiem nie

${ }^{6}$ P. H. Hirst, Liberal Education and the Nature of Knowledge, w: tenże, Knowledge and the curriculum. A collection of philosophical papers, London-Boston 1975, s. 88.

7 Tamże, s. 89. 
tylko postęp w wymiarze tego, co wartościowe, ale ponadto jest związana $\mathrm{z}$ rozwojem intelektualnym i zdolnością rozumienia. Odnosi się ona do całego człowieka, wykluczając kształcenie w ramach wąskiej specjalizacji. Idea liberal education przejawiała się w pojmowaniu edukacji jako działania na rzecz samego siebie, gdzie wiedza pozwala na rozwój wrażliwości oraz refleksyjności wobec rzeczywistości i innych ludzi. Dlatego idea wyedukowanego człowieka odnosi się do jednostki, która odnajduje satysfakcję w różnorodności podejmowanych działań na rzecz własnego rozwoju, skoncentrowanego wokół rozumienia i wrażliwości. Chodzi tu przede wszystkim o nieinstrumentalny aspekt bycia wyedukowanym, które odzwierciedla się w działaniu na rzecz samego siebie.

Przyjęta interpretacja liberal education wpisuje się w sformułowaną przez Association of American Colleges and Uniwersities tezę, która postuluje jej rozumienie w formie podejścia (ang. approach) umożliwiającego jednostkom dysponowanie nie tylko szeroko rozumianą wiedzą z zakresu przedmiotów humanistycznych, społecznych bądź ścisłych, lecz także wskazuje na możliwość dysponowania określonymi umiejętnościami (ang. transferable skills) oraz demonstrowaniem ugruntowanej hierarchii wartości i społecznego zaangażowania ${ }^{8}$.

W podjętych rozważaniach edukację liberalną należy rozumieć nie jako specyficzną formę wiedzy, ale filozofię edukacji, mającą na względzie przede wszystkim określone podejście do uczenia się i nauczania. Współcześnie, między innymi w pracach filozofa edukacji R. S. Petersa, zwraca się uwagę na umiejętności i kompetencje educated person, dla której zdobywanie i posiadanie wiedzy stanowi istotny element życia, umożliwiający samodzielne, dojrzałe poszukiwanie oraz odnajdywanie związków i relacji mających miejsce w otaczającej ją rzeczywistości, które wykraczają poza powierzchowne oraz bierne przyjmowanie informacji ${ }^{9}$. Peters, pisząc o znaczeniu edukacji, wyznaczył jej trzy kryteria, wskazując jednocześnie na horyzont znaczeniowy edukacji liberalnej ${ }^{10}$. Edukacja oznacza przekazywanie tego, co uważa się za wartościowe, osobom, które są czynnie i dobrowolnie zaangażowane $\mathrm{w}$ jej odbiór. Nie oznacza to jednak, że przekazywane treści są obiektywnie wartościowe. Przez samą jednostkę są one postrzegane jako ważne $\mathrm{i}$ istotne. Kolejno, edukacja musi nawiązywać do wiedzy, jej rozu-

8 What is a $21^{\text {st }}$ Century Liberal Education?, Źródło: http://www.aacu.org/leap/What_ is_liberal_education.cfm (dostęp: 21.09.2014).

${ }^{9}$ C. Winch, J. Gingell (red.), dz. cyt., s. 122.

${ }^{10}$ R. S. Peters, Ethics and Education, London 1970, s. 45. 
mienia oraz procesów poznawczych ${ }^{11}$. Trzecie kryterium opisuje edukację wykluczajacą elementy procesu nauczania i uczenia się, które odzwierciedlają brak dobrowolności, motywacji, chęci bądź przymus. W związku z tym edukacja obejmuje ten rodzaj zobowiązania jednostki, który wynika z jej wewnętrznych potrzeb, refleksji i świadomości. Metody edukacyjne nieuwzględniające jednostki jako wolnej i racjonalnej istoty znajdują się poza sferą pojęciową edukacji, czyli także edukacji liberalnej.

Kompetencje oraz umiejętności zawierające się w liberal education mają na celu przygotowanie jednostki do funkcjonowania w rzeczywistości wyróżniającej się różnorodnością, złożonością oraz dynamiczną strukturą. Sprzyjają one również intelektualnej odporności, gotowości podjęcia nauki przez całe życie (ang. lifelong learning) oraz etycznej akceptacji i odpowiedzialności za konsekwencje inicjowanych działań ${ }^{12}$.

Perspektywa przyjętego przez autora obszaru refleksji uwzględnia płaszczyznę interpretacji liberal education, odnosząc ją również do określeń związanych z własnościami (ang. qualities) umysłu ${ }^{13}$. Na uwagę zasługują przede wszystkim umiejętności efektywnego myślenia, porozumiewania się, formułowania wartościowych sądów, podejmowania efektywnych decyzji oraz świadomego i odpowiedzialnego poruszania się w świecie wartości. Sztuka twórczego analizowania problemów oraz dostrzeganie uniwersalnych prawd w określonych sytuacjach decydują o zdolności efektywnego myślenia, które wykracza poza potocznie interpretowane logiczne rozumowanie. Obejmuje ono nie tylko zdolność abstrakcyjnego myślenia, ale także umiejętność formułowania myśli oraz podejmowania adekwatnych działań w obliczu określonego rodzaju problemu. Ponadto, nieodłączną cechą efektywnego myślenia jest komunikacja, w której wyróżnia się głównie zdolność pisania, czytania, mówienia oraz słuchania. Jakkolwiek są one powszechnie uważane za nierozłącze elementy procesu porozumiewania się i niewątpliwie postrzegane jako elementy konstruktywnej komunikacji, dostrzega się ich zaniedbywanie we współczesnej kulturze. Problematyczna kwestia powstawania konfliktów interpersonalnych, których źródłem jest nierzadko wadliwa i destruktywna komunikacja, stanowi w głównej mierze przedmiot refleksji

11 Tamże, s. 30-32.

12 C. Winch, J. Gingell (red.), dz. cyt., s. 23.

13 Próba zdefiniowania terminu liberal education w projekcie Harvard Committee Report: General Education in a Free Society jest rozpatrywana dwojako - w terminach własności umysłu oraz form wiedzy. Niniejsze rozważania koncentrują się przede wszystkim na pierwszym sposobie ujmowania liberal education. Zob. P. H. Hirst, dz. cyt., s. 92. 
oraz praktyki mediacji. Dlatego przede wszystkim w szczerości, otwartości oraz empatii dostrzega się doniosłych wartości w dochodzeniu do wspólnego porozumienia skonfliktowanych stron, którego zasadniczą funkcją jest uwzględnianie potrzeb obu stron ${ }^{14}$. Trzecia umiejętność formułowania wartościowych sądów oraz podejmowania słusznych decyzji wiąże się nie tylko ze zdolnością efektywnego zastosowania posiadanej wiedzy w praktyce, ale także gotowością jednostki do formułowania twórczych rozwiązań. Ostatnia kategoria umiejętności dotyczy świata wartości, a szczególnie zasad fair play, poczucia samokontroli, miłości do prawdy czy wartości estetycznych.

\section{Wariacje na temat mediacji}

Społeczna funkcja mediacji czyni ją atrakcyjną zarówno w znaczeniu koncepcji rozwiązywania konfliktów, jak i strategii prowadzenia konstruktywnej komunikacji. Dalszy etap rozważań koncentruje się na mediacji, jako metodzie konstruktywnego rozwiązywania konfliktów. Kompetencje oraz wynikające z nich umiejętności zarządzania konfliktem składają się na prezentowaną przez jednostkę postawę w sytuacji potencjalnie dla niej trudnej.

Instytucja mediacji, obok negocjacji oraz arbitrażu, stanowi alternatywny sposób rozwiązywania sporów $(\mathrm{ADR})^{15}$. Jej geneza wiąże się z dziedziną prawa, zakorzeniając się tym samym mocno $\mathrm{w}$ formalnoprawnych procedurach sądowych. Nie oznacza to jednak, że pozostaje ona bez związku $\mathrm{z}$ innymi dziedzinami nauki. Prowadzone rozważania ujmują mediację w jej społecznej perspektywie, koncentrując się przy tym na szerokim spektrum zastosowania mediacji, nie ograniczając jej roli tylko do procedur prawnych.

Problematykę mediacji uwzględnia się w kontekście teorii konstruktywnego sporu, którą można rozpoznać już w dziełach Arystotelesa i praktykowanym przez niego rozważnym dyskursie. Składa się na niego uprzednio dyskusja dotycząca pozytywnych oraz negatywnych stron proponowanych rozwiązań, a następnie ich synteza ukierunkowana na sformułowanie alter-

${ }^{14}$ Dyskurs mediacyjny stanowi racjonalny oraz sekwencyjny proces komunikacyjny, prowadzony między dwoma stronami sporu przy udziale osoby trzeciej w postaci mediatora.

${ }^{15}$ ADR - Alternative Dispute Resolution to ,[...] polubowne i pojednawcze sposoby rozwiązywania konfliktów i sporów oparte na idei dążenia do porozumienia oraz znalezieniu kompromisowego wyjścia z sytuacji konfliktowej”. Zob. A. Zienkiewicz, Mediacja sadowa i pozasądowa. Zarys wyktadu, Warszawa 2009, s. 26. 
natywnych rozwiązań ${ }^{16}$. Obok debaty, poszukiwania zgodności oraz tendencji indywidualistycznych najbardziej efektywne i korzystne dla biorących w nim udział stron jest prowadzenie konstruktywnego sporu, które gwarantuje mediacja.

Istota mediacji przejawia się w jej możliwościach zarządzania konfliktem przy udziale trzeciej strony, która wobec stron konfliktu jest bezstronna oraz neutralna ${ }^{17}$. Co więcej, należy także zwrócić uwagę na nadrzędną rolę mediacji, która wyrażona jest $\mathrm{w}$ samostanowieniu stron ${ }^{18}$. W praktyce wiąże się ona z posiadaniem przez strony sporu wyłącznej władzy w decydowaniu o kształcie porozumienia. Mediator nie stanowi autorytarnej kontroli nad procesem kształtowania umowy, dlatego jego funkcja kojarzona jest nierzadko z opiekunem bądź menedżerem przestrzeni komunikacji. Ponadto, funkcja samostanowienia stron decyduje także o podejmowaniu przez jednostki realnej odpowiedzialności za rozwiązanie konfliktu. W kontekście problematyki demokratyzacji społeczeństwa oraz jego możliwości w podejmowaniu autonomicznych prób dochodzenia do porozumienia, koncepcja liberal education realizuje postulaty odnoszące się do postrzegania jednostki jako wolnej oraz zdolnej do wyrażania własnej woli. Idea mediacji, jako pozasądowa forma rozwiązywania sporów, powierza jednostce autonomiczną rolę $\mathrm{w}$ procesie podejmowania decyzji, które jej dotyczą.

Głównym zadaniem instytucji mediacji jest doprowadzenie do porozumienia, które uwzględniając interesy oraz potrzeby obu stron, decyduje o jej doniosłej wartości w rozwiązywaniu konfliktów ${ }^{19}$. Koncentracja mediacji na realizacji potrzeb jednostek stanowi o jej fundamentalnej roli w rozwiązywaniu konfliktów oraz determinacji odbudowy pozytywnych relacji między stronami konfliktu. Interpretowanie przez jednostki konfliktu jako konstruktywnej alternatywy współpracy powoduje kolejno ich wzajemne samopoznanie, samodoskonalenie oraz rozwój moralny, który, co ważne, traktowany jest nie tylko jako korzyść jednostkowa, ale także ogólnospołeczna.

${ }^{16}$ D. W. Jonson, R. T. Johnson, D. Tjosvold, Konstruktywny spór: Wartość intelektualnej opozycji, w: P. T. Coleman (red.), Rozwiązywanie konfliktów: teoria i praktyka, Kraków 2005, s. 66 .

17 Szerzej do sposobów rozumienia mediacji odnosi się Zienkiewicz, prezentując szeroki wybór literatury przedmiotu. Zob. A. Zienkiewicz, Studium, s. 31-54.

18 Tamże, s. 35.

19 Porozumienie, które stanowi końcowy rezultat procesu mediacji, nazywane jest także sytuacją win-win. W odróżnieniu od kompromisu zawieranego w procesie negocjacji, porozumienie ze swej istoty spełnia wymóg uwzględnienia potrzeb obu stron. Natomiast sytuacja kompromisu zmusza jednostkę do rezygnacji z określonych interesów bądź potrzeb. 
W związku z tym sukcesu mediacji nie upatruje się w samym podpisaniu przez strony porozumienia, ale $\mathrm{w}$ zmianach, które zachodzą $\mathrm{w}$ prezentowanych przez jednostki postawach. Reformy o charakterze jakościowym, które demonstrują się przekształceniami w zachowaniu innych ludzi dotyczą w szczególności pozytywnego postrzegania sytuacji konfliktowej jako potencjalnego katalizatora innowacyjnych pomysłów oraz podejmowania współpracy na partnerskich zasadach. Literatura przedmiotu wskazuje na potencjał mediacji, który wyraża się także w rozwijaniu u stron sporu postawy self-determination, która odnosi się kolejno do wzrostu wiary jednostki we własne siły, poczucia wartości, godności, jak i przekonania o słuszności podejmowanych decyzji ${ }^{20}$. Co więcej, uczestnictwo w dyskursie mediacyjnym umożliwia jednostkom odbudowanie pozytywnych relacji poprzez wywołanie w sobie wzajemnie zrozumienia oraz poczucia empatii ${ }^{21}$.

Omówienie naczelnych elementów, które składają się na efektywność dyskursu mediacyjnego, postuluje powołanie się na katalog zasad, stanowiących istotę omawianej koncepcji, a są nimi bezstronność, neutralność, autonomia konfliktu, poufność, odformalizowanie mediacji, dobra wiara oraz szacunek $^{22}$.

Zasada dobrowolności łączy ze sobą dwa aspekty - wychowawczą funkcję prawa ${ }^{23}$ oraz drugą zasadę autonomii konfliktu. Dobrowolność przejawia się wyrażeniem przez strony zgody zarówno na osobę mediatora, jak i na właściwą procedurę mediacji. Ponieważ mediacja nie może być narzucona, toteż sąd dysponuje możliwością wskazania stronom istniejących alternatyw. Z kolei one same mogą z mediacji zrezygnować bądź odstąpić od niej $\mathrm{w}$ dowolnym momencie. Tym samym autonomia konfliktu realizowana jest przez zwrócenie konfliktu stronom, wskazując je jako jego właścicieli, mających pełną kontrolę nad jego przebiegiem oraz wyborem strategii porozumiewania się. Mediator, realizując funkcję hydraulika komunikacji, przeprowadza diagnozę konfliktu i udziela pomocy w wyborze bardziej efektywnych oraz optymalnych rozwiązań. Kolejno, trzecia i czwarta zasada: bezstronności oraz neutralności, charakteryzują relację mediatora wobec

20 Tamże, s. 43.

${ }^{21}$ Człowiek posiada naturalną zdolność współodczuwania stanów emocjonalnych innych osób. Dyskurs mediacji umożliwia stronom wentylację negatywnych emocji oraz wyrażanie swoich racji na poziomie potrzeb, które pozwalają na prowadzenie autentycznego dialogu, opartego na zrozumieniu oraz poszanowaniu interesów obu stron konfliktu.

22 Tamże, s. 60-62.

${ }^{23}$ Dotyczy do sytuacji, kiedy sprawa zostaje skierowana do mediacji przez sąd. 
przedmiotu konfliktu oraz stron, biorących w nim udział. Dystansuje się on wobec samej sytuacji konfliktowej, pamiętając, że jest ona własnością stron. Dalej, zobowiązany zapewnieniem jednostkom równości, przyjmuje postawę neutralną wobec stron, nie oceniając postaw oraz finalnego kształtu porozumienia. Zasada dobrej wiary dotyczy wszystkich stron, biorących udział w procedurze mediacyjnej. Odzwierciedla się ona głównie w przejawianej motywacji i gotowości do podjęcia działań celem zawarcia porozumienia. W przeciwieństwie do wyroku sądowego, który nierzadko nie spełnia oczekiwań którejś ze stron, zawarcie ugody gwarantuje satysfakcję psychiczną obu uczestników mediacji. Osiągnięcie tego stanu jest możliwe za sprawą prowadzenia dialogu, poszanowania obopólnych potrzeb, interesów jednostek oraz poufności, która stanowi kolejną zasadę mediacji. Odnosi się ona zarówno do mediatora, jak i stron konfliktu, minimalizując ryzyko wykorzystania informacji pozyskanych w trakcie spotkań na temat strony przeciwnej. Dodatkowo zasada poufności aranżuje atmosferę intymności, motywując jednostki do otwartości oraz szczerości. Powyższe elementy korespondują z zasadą szacunku, która obowiązuje strony konfliktu, jak i mediatora. Konstruktywna komunikacja może być zapewniona w odpowiednich warunkach, odzwierciedlających się w słuchaniu siebie nawzajem ${ }^{24}$, nieprzerywaniu, poszanowaniu godności oraz możliwości nieagresywnej ekspresji emocji. Kolejnym, ostatnim ważnym atutem mediacji jest jej odformalizowanie, przejawiające się w braku jednoznacznych regulacji prawnych, odnoszących się do postępowania mediacyjnego.

Problematyka mediacji decyduje o konieczności zwrócenia uwagi na sposób rozumienia terminu konflikt. Zagadnienie teorii konfliktu znajduje się w obszarze zainteresowań wielu dziedzin nauki, jak psychologia, filozofia społeczna bądź prawo. Dziedziny nauk społecznych kwalifikują konflikt, obok relacji współdziałania i relacji neutralności, do podstawowych interakcji społecznych ${ }^{25}$. W związku z powyższym konflikt uważa się za stały element rzeczywistości społecznej, a podejmowanie prób jego ostatecznej

${ }^{24}$ Podczas gdy słyszenie jest procesem biernym, który zależy od naszego narządu słuchu, słuchanie jest aktywnym procesem uwarunkowanym naszymi umiejętnościami wyrażającymi się świadomymi przejawami aktywnego słuchania oraz motywacji odbierania informacji.

${ }^{25}$ Przyjęta definicja konfliktu nie obejmuje konfliktu wewnętrznego jednostki, odwołując się do jej wymiaru interpersonalnego. W niniejszym opracowaniu konflikt jest postrzegany jako: „interakcja ludzi zależnych od siebie, którzy uważają, że mają niezgodne cele oraz postrzegają siebie nawzajem jako przeszkody w osiągnięciu owych celów". J. P. Folger, M. S. Poole, R. K. Sutman, Konflikt i interakcja, w: J. Stewart (red.), Mosty zamiast murów. O komunikowaniu się między ludźmi, Warszawa 2000, s. 490. 
eliminacji jest daremne i nieefektywne. Co więcej, podejmowanie nieskutecznych strategii rozwiązywania konfliktu nierzadko prowadzi do jego eskalacji, a więc sytuacji, w której zaczynają dominować silne i negatywne emocje oraz motywacja do zwycięstwa bez względu na poniesione koszty (zarówno osobiste, jak i drugiej strony).

Powszechność funkcjonowania konfliktu w rzeczywistości społecznej decyduje o konieczności dysponowania odpowiednimi umiejętnościami oraz kompetencjami przeformułowywania sporów w celu kreowania nowych jakości, stanowiących czynniki rozwoju i potencjału ${ }^{26}$. Konflikt, postrzegany przez jednostki jako czynnik pozytywnych zmian, określany jest jako konstruktywny. Opiera się z reguły na sprzecznych interesach jednostek, warunkując jego pozytywne rozwiązanie. Z kolei podłożem konfliktu destruktywnego jest wadliwa komunikacja oraz wiązanie go przez każdą $\mathrm{z}$ jednostek z odmiennymi wartościami.

Teoria konstruktywnego sporu stanowi bogaty zbiór założeń, odnoszących się do kompetencji, umiejętności, zachowań oraz wiedzy, zapewniających pozytywne rozwiązanie sporu. W celu zrozumienia potencjału i funkcji konfliktu w budowaniu nowej jakości istotna jest świadomość jego wymiaru jako interakcji konstruktywnej lub destruktywnej. Pierwsza płaszczyzna pozwala na realne skoncentrowanie się stron na istniejącym problemie. Druga interakcja charakteryzuje konflikty nierealistyczne, które manifestują się między innymi zachowaniami agresywnymi. Interakcja konstruktywna stanowi istotę niniejszych rozważań, dlatego postrzeganie konfliktu jako możliwego katalizatora innowacyjnych rozwiązań jest niezbędne, by w rezultacie w pełni zrozumieć jego rolę w życiu społecznym. Potencjał konfliktu umiejscawia się w jego pozytywnych funkcjach, które mogą być wykorzystane przez jednostkę. Chodzi zwłaszcza o powstawanie innowacyjnych idei, rozładowywanie negatywnych emocji, weryfikację i precyzowanie wspólnych celów i stymulowanie zmian społecznych, mających na celu zniesienie nierówności społecznych oraz niesprawiedliwości. Konflikty konstruktywne powstają na płaszczyźnie niezgodności celów bądź ich realizacji. Zadaniem stron jest usunięcie nieporozumień oraz podjęcie prób nowatorskich rozwią$z{ }^{27}$. Z kolei konflikty destruktywne stanowią przyczynek do eksponowania przez strony sporu agresji i aktywności zmierzającej do zaszkodzenia, a w konsekwencji do pokonania potencjalnego przeciwnika. Do najczęściej

${ }^{26}$ A. Zienkiewicz, Studium, s. 16.

${ }^{27}$ L. Witkowski, Psychologia rozwiązywania konfliktów. Praktyka radzenia sobie ze sporami, Warszawa 1995, s. 498. 
spotykanych form agresji zalicza się siłę oraz przymus. Konflikty realistyczne, ponieważ są ukierunkowanie na rozwiązanie określonego problemu, posługują się podmiotowymi metodami podejmowania sporu, jak perswazja, negocjacje, mediacje czy głosowanie. Istotna jest wiedza, za sprawą jakiego czynnika konflikty stają się dla stron budujące bądź dewastujące. Należy je przede wszystkim identyfikować w elastyczności, jaką przejawiają strony konfliktu. Większym przystosowaniem oraz łagodnością w natężeniu sporu wykazują się strony konfliktu konstruktywnego. Są one bardziej skłonne do prowadzenia zrównoważonych rozmów oraz przyjmowania różnorodnych zachowań niż osoby konfliktu destruktywnego, charakteryzującego się eskalacją negatywnych postaw. Dodatkowo, strony sporu zmotywowane osiągnięciem celu oraz postrzeganiem siebie jako partnerów interakcji podejmują próby dojścia do wspólnego porozumienia. Przeciwnie jest w przypadku konfliktu destruktywnego, gdzie strony są zmobilizowane pokonaniem przeciwnika. W związku z powyższym postuluje się przyjęcie postawy, która powinna przejawiać jednostka podejmująca konstruktywne strategie rozwiązywania konfliktów. Jedna z ważniejszych zasad mediacji, zwana złota reguła konfliktu, głosi, że ,jestem krytyczny wobec idei, a nie ludzi; próbuję zrozumieć obydwie strony problemu; podkreślam racjonalność w poszukiwaniu najlepszej możliwej odpowiedzi, biorąc pod uwagę dostępne dane"28. Innymi słowy, każda ze stron powinna dążyć do przyjmowania perspektywy patrzenia na problem z punktu widzenia strony przeciwnej. Kompetencje efektywnego porozumiewania się utożsamiane są z umiejętnością spoglądania z różnych perspektyw. Strategia mediacyjna umożliwia nie tylko wejście w realną podmiotową interakcję, ale również nawiązanie dialogu poprzez prawidłowe odbieranie oraz nadawanie komunikatów.

Właściwe stosowanie teorii konstruktywnego sporu przynosi wymierne rezultaty dla uczestników konfliktów. Wyróżnia się trzy wymiary, które podlegają wzrostowi intelektualnemu oraz społeczno-emocjonalnemu ${ }^{29}$, a są nimi: produktywność oraz jakość rozwiązywanego sporu, rozumianego jako umiejętność wyszukiwania efektywnych rozwiązań sporu, i kreatywność, która stanowi bardzo ważny czynnik zmiany w postawach stron. Determinuje ona postrzeganie problemów z nowej perspektywy, decydując przy tym o jakości alternatywnych rozwiązań. Drugi obszar zmian to interpersonalna wzajemna atrakcyjność uczestników, która sprzyja wzrostowi sympatii oraz postaw empatycznych, a tym samym motywuje do podejmowania produk-

\footnotetext{
28 Tamże, s. 71.

29 Tamże, s. 72.
} 
tywnych decyzji. Ważnym czynnikiem zmiany wśród uczestników sporu jest także przedefiniowanie terminu sporu, który nie musi prowadzić do podziałów i antypatii. Trzeci i ostatni wymiar dotyczy poprawy zdrowia psychicznego oraz wzrostu kompetencji społecznych. Umiejętności radzenia sobie ze stresem, emocjami umożliwiają zarówno kreatywne podejście do konfliktów, jak i decydują o poprawie poczucia własnej wartości oraz pewności siebie.

\section{Wnioski}

Dotychczasowe rozważania wymagają sformułowania kilku wniosków o charakterze ogólnym. Liberal education oraz mediacja w swych podstawowych założeniach koncentrują się na jednostce, odwołując się przy tym do postulatów idei Oświecenia, gdzie egalitaryzm oraz rola władzy, ograniczającej się do ochrony praw, gwarantują obywatelom swobodne funkcjonowanie w granicach wolności innego człowieka.

Szczególny kontekst konfliktu, w którym niniejsze rozważania o liberal education zostały umiejscowione, decyduje o konieczności podjęcia refleksji związanej z funkcjonowaniem jednostki w dynamicznie zmieniającej się rzeczywistości. Mediacje oraz umiejętności, którymi powinna wyróżniać się osoba kompetentna w zakresie podejmowania rozwiązywania konfliktów, zawierają się $\mathrm{w}$ postulowanych przez liberal education transferable skills ${ }^{30}$, a są nimi między innymi umiejętności: motywowania innych, asertywnego radzenia sobie z krytyką, zarządzania czasem, wielozadaniowości, poprawnej werbalizacji myśli czy zarządzania konfliktami ${ }^{31}$. Wzrost znaczenia zdolności jednostki do przystosowania się do zmieniającej się dynamicznie rzeczywistości oraz oczekiwań, że będzie ona jednocześnie kompetentnym i świadomym jej uczestnikiem, stawiają przed nią konieczność rozwoju oraz nabywania nowych cech. Liczni badacze powołują się na wyniki badań potwierdzających silną zależność między kompetencjami społeczno-emocjonalnymi i umiejętnościami zarządzania konfliktem a sukcesami w życiu osobistym czy karierze zawodowej ${ }^{32}$.

${ }^{30}$ Transferable skills - umiejętności przechodnie, tj. umiejętności nabyte w trakcie wykonywania jednego zawodu, które mogą być także efektywnie wykorzystane po jego zmianie na inny, np. wielozadaniowość.

${ }^{31}$ D. W. Jonson, R. T. Johnson, D. Tjosvold, dz. cyt., s. 66.

${ }^{32}$ S. V. Sandy, K. M. Cochran, Rozwój umiejętności rozwiązywania konfliktów u dzieci: W okresie od wieku przedszkolnego po dorastanie, w: P. T. Coleman (red.), dz. cyt., s. 313. 
Liberal education wskazuje także na własności umysłu, jakie powinny charakteryzować jednostkę wykształconą oraz świadomą osobistego rozwoju. Zdolność formułowania precyzyjnych myśli, abstrakcyjne myślenie skorelowane z twórczym podejściem do codzienności gwarantują intelektualną ciekawość, a tym samym rozwój jednostki. Kompetencje oraz umiejętności mediatora zawierają się w powyższych umiejętnościach, koncentrując się także na wymiarze etycznym podejmowanych przez niego aktywności. Chodzi tu przede wszystkim o utrzymywanie warunków niezakłóconej komunikacji, która opiera się na szczerości, zaufaniu, szacunku oraz poszanowaniu godności w relacji z innym. Dodatkowo, interaktywne słuchanie w powiązaniu z przeformułowaniem oraz reinterpretacją uzyskanych danych umożliwiają podjęcie adekwatnych oraz skutecznych działań wygaszających negatywne emocje stron, doprowadzając do rozwiązania konfliktu.

W obu rozważanych koncepcjach należy także zwrócić uwagę na kategorię odpowiedzialności, która zarówno w mediacji, jak i liberal education jest kojarzona z trasformacjami mającymi miejsce po II wojnie światowej oraz demokratyzacją społeczeństw ${ }^{33}$. Szerokie korzystanie z instytucji mediacji wiąże się z umacnianiem społeczeństwa obywatelskiego. Z kolei postulaty edukacji liberalnej oraz mediacji odnoszą się do rozwijania oraz podnoszenia kultury dyskusji, prowadzenia dialogu i otwarcia na odmienności. Szacunek wobec każdej jednostki znajduje się w relacji do zasady egalitaryzmu, gwarantując jej równość szans oraz respektowanie osobowości.

Postulowana przez liberal education postawa krytycznego myślenia znajduje swoje odzwierciedlenie w koncepcji mediacji. Uczestnik sporu także może stać się menedżerem komunikacji oraz zarządcą konfliktu. Dlatego umiejętność obiektywnego spojrzenia na sytuację potencjalnie konfliktową mobilizuje go do podjęcia działań zmierzających do rozumienia drugiej osoby z zachowaniem reguł obiektywności. Co ważne, prowadzenie postępowania mediacyjnego wymaga od mediatora nie tylko kompetencji krytycznego myślenia, ale także dysponowania otwartym umysłem, doświadczeniem życiowym oraz dystansem do sporu. Wspomniane cechy są możliwe do zinterioryzowania przez jednostkę, jeśli będzie ona podejmować aktywności poszerzające jej umiejętności poznawcze oraz praktyczne.

Przyjęta w artykule humanistyczna optyka funkcjonowania człowieka odwołuje się do jego rozwoju oraz przekraczania siebie, ale także do postrzegania go w wielowymiarowej relacji z otaczającym go światem. Próba

33 A. Folkierska, Sergiusz Hessen - pedagog odpowiedzialny, Warszawa 2005, s. $47-49$. 
uchwycenia możliwości wpisania instytucji mediacji w system założeń liberal education stanowi niełatwe, ale warte podjęcia zadanie. Podejmowane działania jednostki, mające na celu przekraczanie własnego Ja w płaszczyźnie materialnej, społecznej oraz symbolicznej (intelektualnej), zawierają się w nadrzędnych celach mediacji, na przykład w rozwoju moralnym, warunkującym zdolność do samostanowienia, twórczego kreowania własnej rzeczywistości, jak i w podstawowych założeniach fundujących istotę liberal education. W związku z tym można postawić tezę, iż dalsze poszukiwania uwzględniające powyższą koncepcję jako wykładnię dla teoretyczno-praktycznych rozważań mediacji uważa się za stosowne i korzystne dla nich obu.

\section{Variations on a Theme of Mediation in Relation to the Concept of Liberal Education (Summary)}

A purpose of the article is an attempt of answering the question, whether the institution of mediation can become a part of a system of liberal education assumptions by seeking shared and related meanings for them. The author of the article is deducing them from the subject of deliberations, which is focused on enlightenment characteristics of a free man responsible for creating his own reality. Due to rather insignificant scientific achievements of Polish pedagogical reflections concerning both mediation and liberal education, the following deliberations are considered unoriginal; simultaneously, becoming a possibility of entering into further discussions in the process.

It is not the author's intention to describe liberal education and mediation from the perspective of effects of the formal education, system or course of study, but to focus on their properties, aimed at an intellectual, social and spiritual development of an individual. Therefore, liberal education is defined as the system of assumptions aimed at individual's autonomous development focused on humanistic values. On the other hand, the literature on the subject emphasizes the co-occurrence of many semantic ranges of mediations, resulting, among others, from their authors' adoption of different aims of the procedure of mediation, conditioning the shape of individual mediatory paradigms. Therefore, an operational research model of the mediatory paradigm, which considers important aims adopted in the article of mediation, conditioning the success and effectiveness of the mediatory discourse, constitutes an interpretation of the discussion.

Keywords: liberal education; mediation; education; individual's development; conflict. 


\section{Wariacje na temat mediacji w związku z koncepcją liberal education (Streszczenie)}

Celem artykułu jest refleksja oraz próba odpowiedzi na pytanie, czy instytucja mediacji wpisuje się w system założeń liberal education, poprzez poszukiwanie wspólnych oraz pokrewnych dla nich znaczeń. Autor artykułu wyprowadza je z przedmiotu rozważań, którego centrum stanowią oświeceniowe cechy człowieka wolnego oraz odpowiedzialnego za kreowanie własnej rzeczywistości. Z uwagi na skromny dorobek myśli naukowej na gruncie polskiej refleksji pedagogicznej dotyczącej zarówno mediacji, jak i liberal education, uważa się poniższe rozważania za przyczynkowe, stające się tym samym możliwością podjęcia dalszych dyskusji.

Zamiarem autora nie jest opis liberal education oraz mediacji z perspektywy efektów formalnego kształcenia, systemu lub przedmiotu nauczania, a koncentracja na ich właściwościach, mających na celu intelektualny, społeczny oraz duchowy rozwój jednostki. Dlatego liberal education zostaje ujęte jako system założeń, mający na celu autonomiczny i skoncentrowany na humanistycznych wartościach rozwój jednostki. Z kolei literatura przedmiotu wskazuje na współwystępowanie wielu zakresów znaczeniowych mediacji, wynikających między innymi z przyjmowania przez ich autorów odmiennych celów procedury mediacji, warunkujących z kolei kształt poszczególnych paradygmatów mediacyjnych. Dlatego wykładnią prowadzonych rozważań będzie optymalizacyjny model paradygmatu mediacyjnego, który uwzględnia przyjęte w artykule najważniejsze cele mediacji, warunkujące sukces oraz efektywność dyskursu mediacyjnego.

Słowa kluczowe: liberal education; mediacja; edukacja; rozwój jednostki; konflikt. 
